Dhaka Univ. J. Biol. Sci. 25(2): 169-184, 2016 (July)

\title{
16S rRNA SEQUENCE BASED IDENTIFICATION OF PATHOGENIC GUT MICROBIOTA OF ROHU LABEO ROHITA (HAMILTON-BUCHANAN 1822) AND SILVER CARP HYPOPHTHALMICHTHYS MOLITRIX (VALENCIENNES 1844)
}

\author{
Nusrat Jahan Punom, AKM Mahbub Hasan ${ }^{1}$, Wahida Haque, \\ Mst Khadiza Begum and Mohammad Shamsur Rahman* \\ Department of Fisheries, Faculty of Biological Sciences, University of Dhaka, \\ Dhaka 1000, Bangladesh
}

Key words: Rohu (Labeo rohita), Silver carp (Hypophthalmichthys molitrix), Pathogenic gut microbiota, $16 \mathrm{~S}$ rRNA sequencing, Antibiogram

\begin{abstract}
Rohu (Labeo rohita) and Silver carp (Hypophthalmichthys molitrix) are the most common, popular and commercially important fish of Bangladesh. Pathogenic gastrointestinal bacteria indicate the acceptability or quality hence it influences the economic status of these fish. To investigate the pathogenic gastrointestinal bacteria of these economically important fish of Bangladesh was carried out. Gut microbiota of indigenous Rohu and exotic Silver carp of three different markets of Dhaka metropolitan city were studied using various selective agar media, classical biochemical tests and $16 \mathrm{~S}$ rRNA sequencing. Antibiotic susceptibility of selected isolates was also carried out against 14 antibiotics. Firstly, 216 colonies were differentiated morphologically and among them, 18 isolates were characterized by biochemical properties. Finally, the identification of 10 isolates were confirmed by sequencing the 16S rRNA gene. Total bacterial count (TBC), total Salmonella-Shigella and total Staphylococcal count exhibited significant difference $(\mathrm{p}<0.05)$ between the species but not among markets. TBC of Rohu samples was $5.27 \pm 2.01 \times 10^{7} \mathrm{cfu} / \mathrm{g}$ and in Silver carp was $3.02 \pm 1.42 \times 10^{7} \mathrm{cfu} / \mathrm{g}$, total Salmonella and Shigella was $6.94 \pm 7.15 \times 10^{6} \mathrm{cfu} / \mathrm{g}$ from Rohu and $1.11 \pm 0.97$ $\times 10^{6} \mathrm{cfu} / \mathrm{g}$ from Silver carp. Total Staphylococcal count was found $1.03 \pm 0.52 \times$ $10^{7} \mathrm{cfu} / \mathrm{g}$ in Rohu and $5.48 \pm 3.98 \times 10^{6} \mathrm{cfu} / \mathrm{g}$ in Silver carp. Biochemical assays provisionally determined 7 different bacterial genera from Rohu and 7 from Silver carp. Six different genera of Gram-negative bacteria (4 genera from Rohu and 2 from Silver carp) were identified as Aeromonas, Proteus, Pseudomonas, Enterobacter, Citrobacter, Klebsiella sp. by $16 \mathrm{~S}$ rRNA sequencing. The results revealed that all the 18 representative isolates including reference strain (E. coli DH5 $\alpha$ ) were sensitive to ciprofloxacin and resistant to sulphamethoxazole. These findings might be due to the poor quality of the aqueous environment and reflects fish as the potential reservoir of pathogenic bacteria causing fish-borne disease outbreaks.
\end{abstract}

\footnotetext{
*Author for correspondence: <shamsur@du.ac.bd>. ${ }^{1}$ Department of Biochemistry and Molecular Biology, Faculty of Biological Sciences, University of Dhaka, Dhaka 1000, Bangladesh.
} 


\section{Introduction}

Rohu (Labeo rohita) is a fast growing omnivorous Indian major carp. This diurnal, column feeder mostly depends on the planktonic, filamentous algae, aquatic plant leaves, phytoplankton, zooplankton and also small insects in a minor amount ${ }^{(1)}$. In Bangladesh, Rohu has huge demand as common food fish due to its high palatability and great nutritional value. The Silver carp (Hypophthalmichthys molitrix) is a stomach-less, filterfeeder freshwater cyprinid which feed on both phytoplankton and zooplankton(2). In many countries of the world, Silver carp has been introduced as a food fish or a way to control plankton populations ${ }^{(3)}$. In 1969, it was introduced in Bangladesh (en.banglapedia.org /index.php?title=Exotic_Fish). Among major carps, Rohu provides the highest contribution as $10.91 \%$ and among 12 exotic fishes, Silver carp also confers the highest contribution as $8.79 \%$ in the annual fish production of inland water of Bangladesh $^{(4)}$.

The digestive tract of fish provides a suitable growth environment for microorganisms ${ }^{(5)}$. Gut microbiota of fish are ecological community of commensal, symbiotic and pathogenic microorganisms that literally share the gastrointestinal tract of a fish. The host's genetic background, life style, feeding habit and selective pressures of gut habitats can be regulated by the composition of gut microbiota ${ }^{(6,7)}$. Therefore, it is important to understand the pathogenic gut microbiota which would certainly provide an insight into their role in fish health in order to improve fish quality or acceptability, thereby improving aquaculture.

A high density of Vibrio, coliform, fecal Streptococci, Pseudomonas, Aeromonas, Brevundimonas, Massilia, Curvibacter, an unclassified Sphingobacteriales genus, Bacillus, Enterobacter, Anoxybacillus, Clostridium, Actinomyces, Citrobacter were confirmed by many studies which ensure the presence of different pathogenic gut microbiota in Silver $\operatorname{carp}^{(8-10)}$. Some researchers also revealed pathogenic gut microbiota from the gastrointestinal tract of Rohu like - Vibrio, faecal Streptococci, total coliform, Pseudomonas, Aeromonas and Enterobacter $(8,11)$.

All types of pathogenic bacteria can be of health concern to human and fish and can hamper the progress of aquaculture which can adversely affect the economy of a country. Many fishes found to be consolidated with infectious pathogens, can act as vectors of fish-borne disease outbreak of human beings ${ }^{(12)}$. To kill or inhibit the growth of pathogenic bacteria, antibacterial agents can be used. But the fatality rate in human is increasing day by day due to the emergence of microbial resistance to multiple drugs (13). Both therapeutic and environmental problems have been addressed in the field of aquaculture when antimicrobial agents are discharged into the surrounding water during the treatment of bacterial fish diseases ${ }^{(14)}$.

In order to investigate the fish gut microbial diversity most previous studies were performed by conventional culture-dependent or microscopy methods ${ }^{(15,16)}$. Rapid and 
accurate identification of pathogenic gut microbiota have always been a challenge. In this situation, molecular methods have proven helpful to meet this challenge. Among all sequencing platforms, 16S rRNA sequencing technology provides large enough length (1500 bp) for informatics purposes and has been used to investigate bacterial phylogeny and taxonomy ${ }^{(17)}$.

This study was set to identify and characterize the pathogenic gut microbiota of indigenous Rohu and exotic Silver carp based on 16S rRNA sequencing. Moreover, quantitative enumeration of bacterial density, construction of phylogenetic tree and antibiotic susceptibility of the isolated bacteria were performed.

\section{Materials and Methods}

Three replicates of Rohu (Labeo rohita, Hamilton : Buchanan 1822) and Silver carp (Hypophthalmichthys molitrix, Valenciennes 1844) were collected in sterilized plastic bags using insulated ice box from 3 different fish markets (Nobabgonj, Palashi and Anando bazar) of Dhaka Metropolitan city during April, 2015 to December, 2015. Collected fish samples were identified according to Rahman ${ }^{(18)}$. The average length and weight (mean \pm standard deviation) of Rohu were $32.13 \pm 3.75 \mathrm{~cm}$ and $429.43 \pm 162.72 \mathrm{~g}$, respectively. In Silver carp, average length and weight were $39.37 \pm 9.69 \mathrm{~cm}$ and $758.09 \pm 383.36 \mathrm{~g}$, respectively.

After collection of fish, gut samples were aseptically removed following the method of APHA (1998) and separately homogenized with $0.9 \%$ sodium chloride solution using sterilized homogenizer ${ }^{(19)}$. The homogenates were serially diluted and $100 \mu \mathrm{l}$ from $10^{-1}$, $10^{-3}$ and $10^{-5}$ dilution were spread on Luria agar (LA), thiosulphate citrate bile salts sucrose (TCBS), Salmonella-Shigella (SS), Aeromonas Agar, Mannitol Salt Agar (MSA) and Eosin Methylene Blue (EMB) Agar plates ${ }^{(20)}$. After incubation of these plates at $37^{\circ} \mathrm{C}$ for $24 \mathrm{~h}$, total bacterial count (TBC), total Vibrio count (TVC), total Salmonella-Shigella count (TSSC), total Aeromonas count (TAC), total Staphylococcal count (TSC) and total coliform (TC) count were determined and expressed as colony forming units (cfu/g).

After counting, well discrete bacterial colonies of different morphotypes were picked and purified by repeated streaking on TCBS, SS, Aeromonas, MSA and EMB agar plates followed by incubation at $37^{\circ} \mathrm{C}$ for $24 \mathrm{hrs}$. Two hundred sixteen different colonies were purified primarily and finally 18 isolated colonies were selected for biochemical assay. Pure cultures were preserved in $20 \%$ glycerol at $-20^{\circ} \mathrm{C}$ for a couple of months. The present study employed E. coli $\mathrm{DH} 5 \alpha$ as a reference strain.

For presumptive identification of 18 bacterial isolates, biochemical tests were performed according to the protocol of ASM MicrobeLibrary (http://www. microbelibrary.org). Results were confirmed through Bergey's Manual of determinative Bacteriology (21) and ABIS online software (http://www.tgw1916.net bacteria_logare.htm). 
Genomic DNA of 10 presumptively identified bacteria were extracted using a commercial kit (Maxwell 16 MDx Research Instrument, Promega, USA) based on the manufacturer's instruction. The absorbance of purified DNA by NanoDrop spectrophotometer (NanoDrop 2000 UV-Vis spectrophotometer, Thermo Fisher Scientific Inc., USA) was checked at $260 \mathrm{~nm}$.

Extracted DNA from the isolates was amplified by Polymerase Chain Reaction (PCR) of the conserved region of $16 \mathrm{~S}$ rRNA for further analysis. The sequences of oligonucleotide primers used for amplification of the ribosomal subunit 16S rRNA were as follows: 27F 5'- AGA GTT TGA TCM TGG CTC AG -3' and 1492R 5'- CGG TTA CCT TGT TAC GAC TT $-3^{\prime}$, with approximately $1500 \mathrm{bp}$. Reactions of the amplification were conducted in a reaction volume of $25 \mu \mathrm{l}$ containing $12.5 \mu \mathrm{l}$ of Hot Start Colorless Master Mix, $1 \mu \mathrm{l}$ of DNA template, $9.5 \mu \mathrm{l}$ of Nuclease-free water, $1 \mu \mathrm{l}$ of forward and reverse primer. PCR amplification was done in an oil-free thermal cycler (Applied Biosystems 2720 Thermal Cycler). The program initially consisted of the following steps: $95^{\circ} \mathrm{C}$ for 5 min for denaturation, then 32 cycles at $95^{\circ} \mathrm{C}$ for $30 \mathrm{~s}, 48^{\circ} \mathrm{C}$ for $30 \mathrm{~s}$ and $72^{\circ} \mathrm{C}$ for $1 \mathrm{~min} 30$ $\mathrm{sec}$, followed by an extension step at $72^{\circ} \mathrm{C}$ for $5 \mathrm{~min}$. Successful amplification of the desired sequences was visualized by resolving the PCR products in $1 \%$ agarose gel $(\mathrm{w} / \mathrm{N})$ at 100 volts for $60 \mathrm{mins}$ and stained with $2 \mu \mathrm{l}$ of ethidium bromide (H5041, Promega, USA). $1 \mathrm{~kb}$ DNA ladder (Promega, USA) was also electrophoresed along the side of the amplified sample DNA, which served as a reference for the determination of the molecular weights of the fragments obtained in the PCRs. DNA bands were observed and photographed by AlphaImager MINI Gel documentation system (ProteinSimple, USA).

Amplified DNA was further purified with the Wizard PCR SV Gel and PCR CleanUp System kit (Promega, USA) according to the manufacturer's instruction prior to sequencing. Sequencing of PCR products was performed using BigDye Terminator v 3.1 Cycle Sequencing Kit (Applied Biosystems, USA) according to manufacturer's instruction and capillary electrophoresis was done using ABI Genetic Analyzer (Applied Biosystems, USA).

To view DNA sequence Geospiza's Finch TV version 1.4 was used. BLAST (Basic Local Alignment Search Tool) was used for comparing primary sequence information. CLUSTALW was used for multiple sequence alignment (MSA). This helps to find similarity, dissimilarity or identity between different sequences. MEGA v 6.0 was used for the comparative analysis of molecular sequence data for reconstructing the evolutionary histories of species and inferring the nature and extent of selective forces shaping the evolution of genes and species.

Kirby-Bauer disc diffusion technique was performed to determine the sensitivity or resistance of pathogenic bacteria to 14 antibacterial compounds (list of 14 antibiotic disks is given in Table 6). Eighteen presumptively identified isolates were inoculated on LB 
broth and inoculated for 16 hours. The bacterial suspension was then inoculated onto the surface of the Mueller-Hinton agar (HIMEDIA, M173-500G, India) using sterile cotton swabs, which were then left to dry for several minutes. The antibiotic discs (Oxoid, USA) were applied on the surface of the agar plate and incubated for $24 \mathrm{hrs}$ at $37^{\circ} \mathrm{C}$. Finally, the zone of inhibition was measured and compared with the reference data of antibiogram pattern to know the susceptibility of the bacteria (22).

The Statistical Package for the Social Sciences (SPSS) v. 20.0 for windows (SPSS, SAS Institute Inc. Cary, USA) was used for statistical analysis. One way ANOVA was subjected using $5 \%$ level of significance.

The reported sequences in this study have been submitted to GENBANK database under accession numbers KU992678-KU992687.

\section{Results and Discussion}

Results of the quantitative estimation of total bacteria, total Vibrio, total SalmonellaShigella, total Aeromonas, total Staphylococcal and total coliform in Rohu and Silver carp intestine are demonstrated in Table 1. The total bacterial density of Rohu samples was $5.27 \pm 2.01 \times 10^{7} \mathrm{cfu} / \mathrm{g}$ and in Silver carp the density was $3.02 \pm 1.42 \times 10^{7} \mathrm{cfu} / \mathrm{g}$. The total bacterial density of Rohu was significantly higher than Silver carp at $5 \%$ level.

Table 1. Bacterial density, mean \pm SD (cfu/g) in the gut of Rohu and Silver carp measured on LA, TCBS, SS, Aeromonas agar, MSA and EMB agar media. Different letters represent significant differences between Rohu and Silver carp in total bacterial count, total Salmonella- Shigella count, total Staphylococcal count $(\mathrm{p}<0.05)$.

\begin{tabular}{llc}
\hline \multirow{2}{*}{$\begin{array}{l}\text { Bacterial density } \\
(\mathrm{cfu} / \mathrm{g})\end{array}$} & \multicolumn{2}{c}{ Sample name } \\
\cline { 2 - 3 } & Rohu & Silver carp \\
\hline Total bacterial count & $5.27 \pm 2.01 \times 10^{7 \mathrm{a}}$ & $3.02 \pm 1.42 \times 10^{7 \mathrm{~b}}$ \\
Total Vibrio count & $1.58 \pm 3.51 \times 10^{6}$ & $2.38 \pm 3.63 \times 10^{3}$ \\
Total Salmonella- Shigella count & $6.94 \pm 7.15 \times 10^{6 \mathrm{a}}$ & $1.11 \pm 0.97 \times 10^{6 \mathrm{~b}}$ \\
Total Aeromonas count & $1.31 \pm 1.06 \times 10^{7}$ & $6.09 \pm 4.61 \times 10^{6}$ \\
Total Staphylococcal count & $1.03 \pm 0.52 \times 10^{7 \mathrm{a}}$ & $5.48 \pm 3.98 \times 10^{6 \mathrm{~b}}$ \\
Total coliform count & $1.68 \pm 0.98 \times 10^{7}$ & $1.39 \pm 2.35 \times 10^{7}$ \\
\hline
\end{tabular}

Total Salmonella-Shigella was $6.94 \pm 7.15 \times 10^{6} \mathrm{cfu} / \mathrm{g}$ in Rohu and in Silver carp it was $1.11 \pm 0.97 \times 10^{6} \mathrm{cfu} / \mathrm{g}$. Statistically significant $(\mathrm{p}<0.05)$ higher population level of TSSC was found in Rohu compared to Silver carp.

In Rohu, the total Staphylococcal count was $1.03 \pm 0.52 \times 10^{7} \mathrm{cfu} / \mathrm{g}$. However, for Silver carp, the total Staphylococcal count was $5.48 \pm 3.98 \times 10^{6} \mathrm{cfu} / \mathrm{g}$. Significant difference $(p<0.05)$ was found on total Staphylococcal count between these two species. 
No significant difference was found between Rohu and Silver carp in case of total Vibrio, total Aeromonas and total coliform count.

The normal bacterial load of the intestine of fish can range between $10^{3}$ to $10^{9} \mathrm{cfu} / \mathrm{g}$ (23). This supports the present study. The guideline of ICMSF (1986) acceptable limit of the total bacterial count for white fish is $5 \times 10^{5} \mathrm{cfu} / \mathrm{g}$, for total Vibrio count it is $0 \mathrm{cfu} / \mathrm{g}$, for Salmonella spp. $0 \mathrm{cfu} / \mathrm{g}$, Shigella spp. $1 \times 10^{2} \mathrm{cfu} / \mathrm{g}$, for Staphylococcus spp. $>10^{3} \mathrm{cfu} / \mathrm{g}$ and for total coliform count in raw fish it is $100 \mathrm{cfu} / \mathrm{g}$ and for $E$. coli $0 \mathrm{cfu} / \mathrm{g}{ }^{(24)}$. In this study, TBC, TVC, TSSC, TSC and TCC of Rohu and Silver carp exceeded the acceptable limit of ICMSF (1986). This result implies that microbiota harbored in gastrointestinal tract of fish may be related to aqueous environment, feeding habit, sediment and host $(25,26)$. Besides, bad handling, storage condition, hygiene and sanitary maintenance of the local markets are also responsible for these high values.

Table 2 illustrates the presumptively identified bacterial isolates of Rohu and Silver carp through biochemical tests. Out of 18 isolates, 3 were gram-positive and the remaining 15 were gram-negative bacteria. In the present study, 7 different genera (Vibrio, Aeromonas, Proteus, Pseudomonas, Staphylococcus, Enterobacter, Klebsiella sp.) from Rohu and 7 different genera (Vibrio, Salmonella, Aeromonas, Pseudomonas, Staphylococcus, Escherichia, Klebsiella sp.) from Silver carp were provisionally identified by biochemical assay.

Table 2. Presumptively identified bacterial isolates of Rohu and Silver carp through Biochemical tests (9 from each species of fish).

\begin{tabular}{ll}
\hline Identified bacterial sp. of Rohu & Identified bacterial sp. of Silver carp \\
\hline Vibrio metschnikovil & Vibrio furnissii \\
Aeromonas sp. & Salmonella sp. \\
Proteus mirabilis & Aeromonas sp. \\
Pseudomonas citronellolis & Pseudomonas graminis \\
Aeromonas salmonicida & Aeromonas salmonicida \\
Staphylococcus caprae & Staphylococcus aureus \\
Pseudomonas sp. & Staphylococcus carnosus \\
Enterobacter nimipressuralis & Escherichia coli \\
Klebsiella oxytoca & Klebsiella pneumoniae \\
\hline
\end{tabular}

Amplification of $16 \mathrm{~S}$ rRNA gene of 10 isolates was carried out using universal primer pair $27 \mathrm{~F}$ and $1492 \mathrm{R}^{(27)}$. PCR products of 10 different isolates analyzed by $1 \%$ gel electrophoresis revealed a single fragment of $1.5 \mathrm{~kb}$ (Fig. 1). Comparison with known $16 \mathrm{~S}$ rRNA sequences in the NCBI GenBank using the BLAST program showed that the sequence of all 10 strains were $99 \%$ to $100 \%$ similar (Table 3). 
Table 3. Similarity percentage with GenBank Accession number of $16 \mathrm{~S}$ rRNA sequence of 10 identified strains compared to those obtained from BLAST search.

\begin{tabular}{|c|c|c|c|c|c|}
\hline $\begin{array}{l}\text { Isolate } \\
\text { no. }\end{array}$ & Source & $\begin{array}{l}\text { Closest relative } \\
\text { (obtained from BLAST search) }\end{array}$ & $\begin{array}{l}\text { \% homology } \\
\text { with the } \\
\text { GenBank } \\
\text { sequence }\end{array}$ & $\begin{array}{c}\text { GenBank accession } \\
\text { number of } \\
\text { corresponding } \\
\text { sequence } \\
\end{array}$ & $\begin{array}{c}\text { GeneBank } \\
\text { accession number } \\
\text { of isolates under } \\
\text { present study }\end{array}$ \\
\hline njp1 & Rohu & Aeromonas hydrophila subsp. dhakensis strain SSE50 & 100 & KF769535 & KU992678 \\
\hline njp2 & $"$ & Proteus penneri strain wf-3 & 100 & KT029132 & KU992679 \\
\hline njp3 & $"$ & Pseudomonas plecoglossicida strain Pp20 & 99 & KU321233 & KU992680 \\
\hline njp4 & $"$ & Aeromonas caviae strain J5 & 99 & КР262417 & KU992681 \\
\hline njp5 & $"$ & Enterobacter sp. UIWRF1185 & 99 & KR189394 & KU992682 \\
\hline njp6 & $"$ & Pseudomonas aeruginosa strain R4 & 99 & KU321274 & KU992683 \\
\hline njp7 & Silver carp & Aeromonas sp. ID1 & 100 & KT695849 & KU992684 \\
\hline njp8 & $"$ & Citrobacter freundii strain BCD12 & 99 & KT156814 & KU992685 \\
\hline njp9 & $"$ & $\begin{array}{l}\text { Klebsiella pneumoniae subsp. rhinoscleromatis strain } \\
\text { HE17 }\end{array}$ & 99 & LN624806 & KU992686 \\
\hline njp10 & $"$ & $\begin{array}{l}\text { Klebsiella pneumoniae subsp. rhinoscleromatis strain } \\
\text { HE17 }\end{array}$ & 99 & LN624806 & KU992687 \\
\hline
\end{tabular}


$1341 \mathrm{bp}$ of DNA sequences was further used for multiple sequence alignment. After comparing the obtained sequences of 3 Aeromonas sp. (njp1, njp4 and njp7), a total 20 sites were found polymorphic (Table 4). The dissimilarity was $1.49 \%(20 / 1341=0.0149)$. njp7 was isolated from Silver carp whereas, the other 2 (njp1 and njp4) were isolated from Rohu samples.

Table 4. List of polymorphic positions and nucleotides of njp1, njp4, njp7.

\begin{tabular}{ll}
\hline Isolates no. & Dissimilar position and nucleotides \\
\hline njp1 & $154(\mathrm{G}), 553(\mathrm{G}), 915(\mathrm{~T}), 922(\mathrm{~A})$ \\
njp4 & $643(\mathrm{~A})$ \\
njp7 & $33(\mathrm{G}), 35(\mathrm{~T}), 36(\mathrm{C}), 58(\mathrm{~T}), 59(\mathrm{~A}), 60(\mathrm{C}), 69(\mathrm{G}), 70(\mathrm{~T}), 71$ \\
& $(\mathrm{~A}), 134(\mathrm{G}), 135(\mathrm{~A}), 136(\mathrm{~A}), 168(\mathrm{C}), 1213(\mathrm{C}), 1234(\mathrm{G})$ \\
\hline
\end{tabular}

Similarly, in 2 Pseudomonas sp. (njp3 and njp6) 52 polymorphic positions were found. Thus, the variation in the base pair was $3.88 \%(52 / 1341=0.0388)$. Both sequences were isolated from Rohu sample.

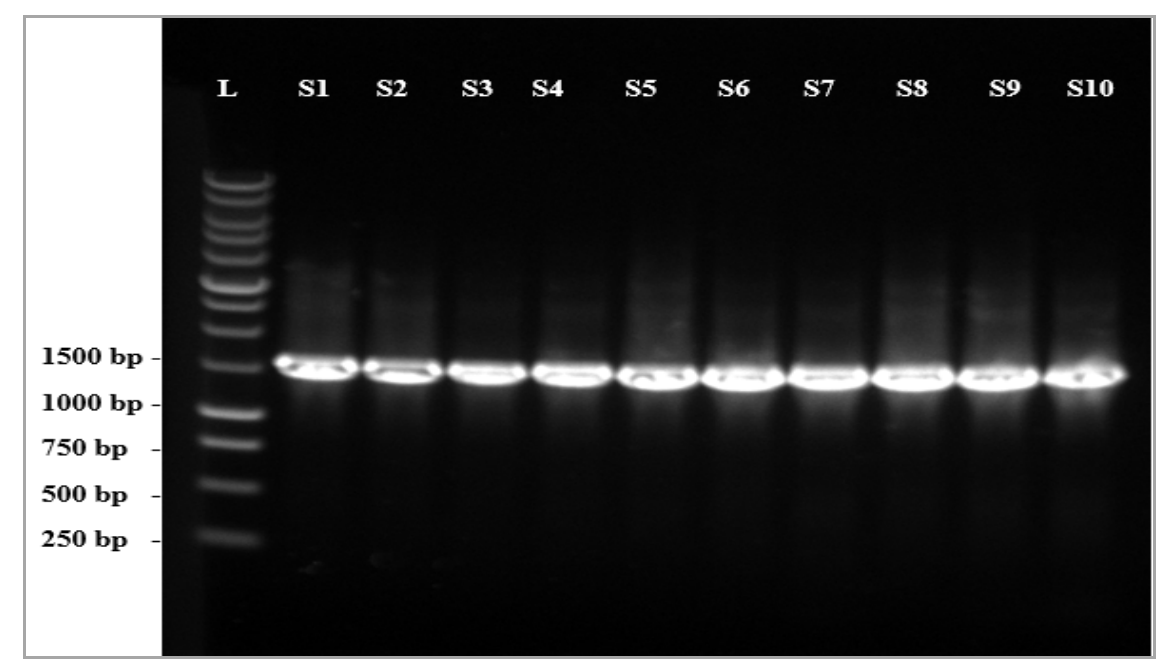

Fig. 1. PCR amplification of $1492 \mathrm{bp} 16 \mathrm{~S}$ rRNA gene of 10 different isolates: Lane 1$10=\mathrm{S} 1$ to $\mathrm{S} 10$ denotes njp1 to njp10 and L denotes DNA ladder, $1 \mathrm{~kb}$ (Marker).

Out of 10 sequences, 2 (njp9 and njp10) showed similar identity (Klebsiella pneumoniae subsp. rhinoscleromatis). But in multiple sequence alignment (MSA) these 2 (njp9 and njp10) were almost similar to each other except in 3 positions (338, 361 and 1038) which were polymorphic (Fig. 2).

Phylogenetic analysis was made through the construction of a phylogenetic tree (Fig. 3) based on the partial 16S rDNA gene sequences of the representative 10 isolates using 
neighbor-joining and BioNJ algorithms. This confirmed the taxonomic position of the isolates (njp1 to njp10) and the difference of these bacterial strain sequences with other homologous bacterial sequences. Twenty six nucleotide sequences (10 experimented sequences with 16 downloaded sequences from NCBI GenBank) were used for the construction of the phylogenetic tree that supported the findings of multiple sequence alignment.

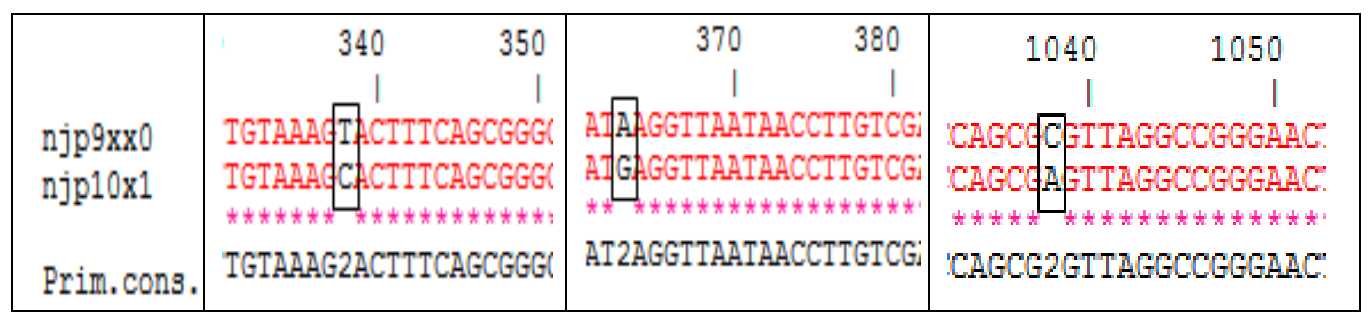

Fig. 2. Multiple sequence alignment of $16 \mathrm{~S}$ rRNA gene fragments of the closely related group njp9 and njp10 where black boxes among the red indicates polymorphic sites. (CLUSTALW, alignment width 120).

Isolates njp1 and njp4 were found to be closely related to njp7 which supports their similarity with Aeromonas hydrophila subsp. dhakensis strain SSE50, Aeromonas caviae strain J5 and Aeromonas sp. ID1, respectively.

Two isolates (njp1 and njp4) of Rohu showed 100\% similarity to Aeromonas hydrophila and Aeromonas caviae, respectively; and one isolate (njp7) of Silver carp showed 99\% similarity to Aeromonas sp. Aeromonas sp. is Gram-negative, motile and have been ubiquitously found from freshwater, fish and shellfish and also from meats and fresh vegetables ${ }^{(28)}$. Some researchers confirmed the presence of Aeromonas sp. in the gut of Rohu and Silver carp ${ }^{(10,11)}$. Different enzymes like- protease, amylase are produced by Aeromonas sp.(29) The presence of Aeromonas spp. could be the cause of different life threatening illness like liver cirrhosis, eye infection, fatal septicemia to human being(30,31). Besides human being, fishes are also inflicted by different diseases like- hemorrhagic disease, ulcerative disease, furunculosis and septicemia because of the presence of Aeromonas spp. in water body(32).

It is clear from the phylogenetic tree (Fig. 3) that njp9, njp10 are closely related to Klebsiella pneumoniae subsp. rhinoscleromatis strain HE17 and Klebsiella sp. KB 52. Klebsiella pneumoniae subsp. rhinoscleromatis (njp9 and njp10) was identified only in the gut sample of Silver carp. These two strains showed $99 \%$ similarity to the partial sequence of the $16 \mathrm{~S}$ rRNA region of Klebsiella pneumoniae subsp. rhinoscleromatis.

The phylogenetic tree also confirmed the taxonomic position of njp3 and njp6 in the genus Pseudomonas supporting their similarity with Pseudomonas plecoglossicida strain Pp20 and Pseudomonas aeruginosa strain R4, respectively. 


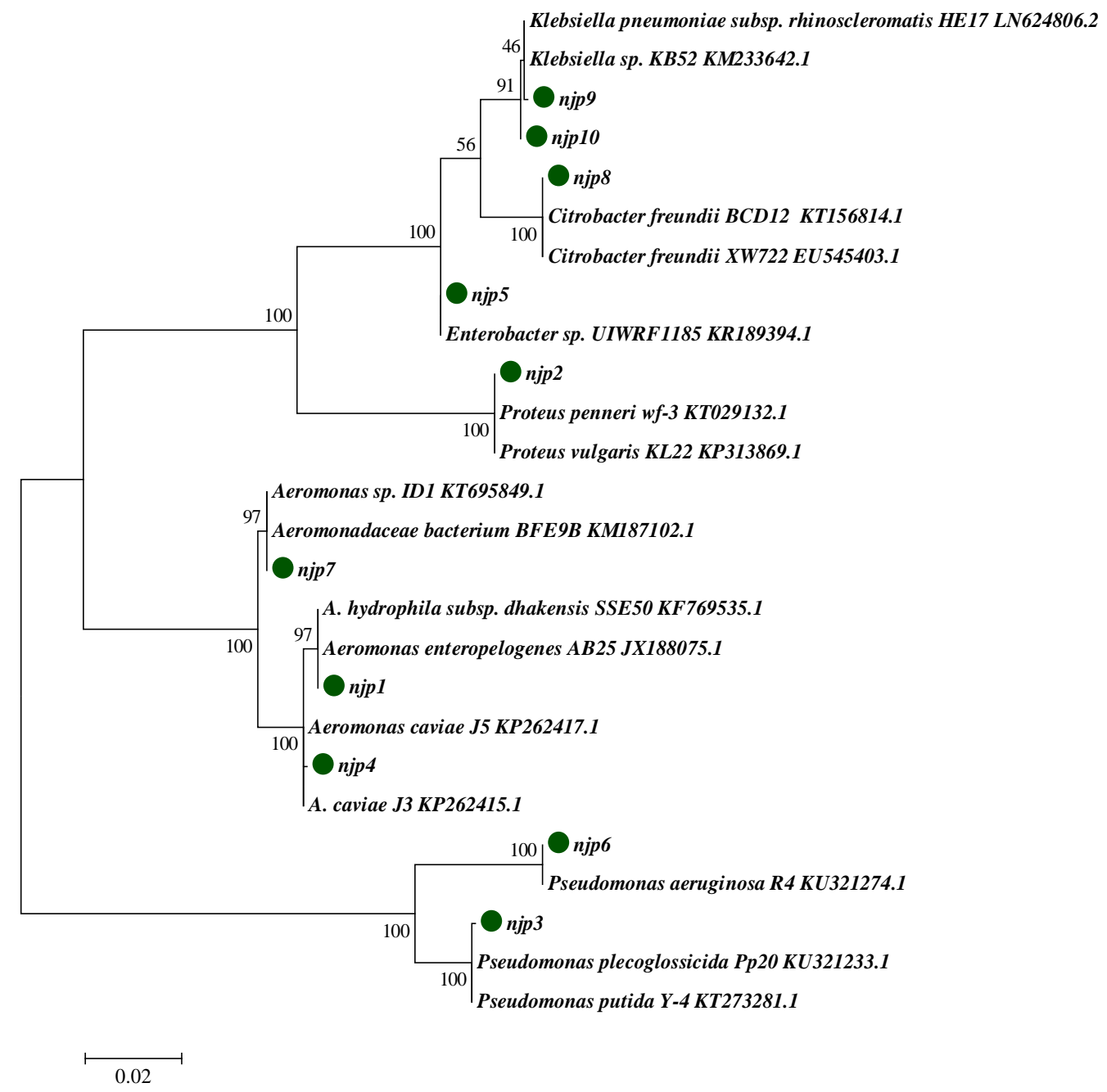

Fig. 3. The neighbor-joining (NJ) phylogenetic tree based on partial $16 \mathrm{~S}$ rRNA gene sequences conducted using MEGA v.6. The evolutionary distances were compared by Maximum Likelihood method, bootstrap 1000 replicates. Green circles indicate position of the studied strains.

Pseudomonas plecoglossicida and Pseudomonas aeruginosa were identified by $16 \mathrm{~S}$ rRNA sequencing from Rohu samples only. These are gram-negative, motile and oxidasepositive ${ }^{(33)}$. Some scientists established the occurrence of Pseudomonas sp. in the digestive tract of Rohu ${ }^{(34,35)}$. Pseudomonas aeruginosa has some infectious activity in the human body such as- bacteraemia in burn victims, urinary tract infections in catheterized patients and hospital-acquired pneumonia in patients on respirators ${ }^{(36)}$. Protease and lipase enzyme 
can be produced by Pseudomonas sp. to degrade protein and lipid(29). Biofilm formation of Pseudomonas sp. potentially reflects their pathogenicity ${ }^{(37)}$.

The tree also supports the taxonomic position of njp2, njp5 and njp8 as the genus Proteus, Enterobacter and Citrobacter are found similar to Proteus penneri strain wf-3, Enterobacter sp. UIWRF1185 and Citrobacter freundii strain BCD12, respectively. Identified Proteus penneri is a Gram-negative bacteria( ${ }^{(38)}$. Several investigations reported their inhabitance in Rohu ${ }^{(35,39)}$.

Enterobacter sp. and Proteus penneri were isolated previously from Rohu(35,40). Their presence in fish gut may possibly correlate with its feeding habit.

Other species, like Citrobacter freundii was identified from Silver carp. Citrobacter is also a cellulose degrading bacteria( ${ }^{(5)}$. The common distribution of Citrobacter strains is the human and animal intestine, soil, water, sewage, food and fish gut ${ }^{(41)}$.

Identification was performed considering all morphological, biochemical and molecular characters of the isolated organisms. Out of 18 provisionally identified sp. 10 isolates were further used for molecular identification. Among 10 identified species, 6 species were found to be similar up to the genus level both in provisional and molecular identification (Table 5). Among 6 identified species 4 bacterial species were isolated from Rohu sample and 2 from Silver carp.

Table 5. List of identified species by provisional and molecular method (bold letters illustrate similar identification up to genus using both biochemical and molecular methods).

\begin{tabular}{|c|c|c|}
\hline $\begin{array}{l}\text { Isolate } \\
\text { no. }\end{array}$ & $\begin{array}{l}\text { Identified sp. by provisional } \\
\text { method }\end{array}$ & $\begin{array}{l}\text { Identified sp. by molecular } \\
\text { method }\end{array}$ \\
\hline njp1 & Vibrio metschnikovil & Aeromonas hydrophila subsp. dhakensis \\
\hline njp2 & Proteus mirabilis & Proteus penneri \\
\hline njp3 & Pseudomonas citronellolis & Pseudomonas plecoglossicida \\
\hline njp4 & Staphylococcus caprae & Aeromonas caviae \\
\hline njp5 & Enterobacter nimipressuralis & Enterobacter sp. \\
\hline njp6 & Pseudomonas sp. & Pseudomonas aeruginosa \\
\hline njp7 & Aeromonas sp. & Aeromonas sp. \\
\hline njp8 & Pseudomonas graminis & Citrobacter freundii \\
\hline njp9 & Staphylococcus aureus & Klebsiella pneumoniae subsp. rhinoscleromatis \\
\hline njp10 & Klebsiella pneumonia & Klebsiella pneumoniae subsp. rhinoscleromatis \\
\hline
\end{tabular}

The percentages of antibiotic susceptibility of the isolates to different antibiotics are summarized in Table 6. All isolates of Rohu and Silver carp including reference strain were resistant to sulphamethoxazole whereas they were sensitive to ciprofloxacin. Around $89 \%$ isolates of Rohu and all isolated strains of Silver carp were resistant to ampicillin and amoxycillin. 
Table 6. Percentage of antibiotic susceptibility for 18 isolates against 14 antibiotics where R, I, S denotes Resistant, Intermediate and Sensitive.

\begin{tabular}{|c|c|c|c|c|c|c|}
\hline \multirow[t]{2}{*}{ Name of Antibiotics } & \multicolumn{3}{|c|}{$\begin{array}{l}\text { Isolates of Labeo rohita } \\
\qquad(\mathrm{N}=9)\end{array}$} & \multicolumn{3}{|c|}{$\begin{array}{l}\text { Isolates of Hypophthalmichthys molitrix } \\
\qquad(\mathrm{N}=9)\end{array}$} \\
\hline & $\mathrm{R}(\%)$ & $\mathrm{I}(\%)$ & $\mathrm{S}(\%)$ & $\mathrm{R}(\%)$ & $\mathrm{I}(\%)$ & $\mathrm{S}(\%)$ \\
\hline Amikacin $(30 \mu \mathrm{g})$ & $1(11.11)$ & $1(11.11)$ & $7(77.78)$ & $1(11.11)$ & $1(11.11)$ & $7(77.78)$ \\
\hline Nitrofurantoin $(300 \mu \mathrm{g})$ & $4(44.44)$ & $1(11.11)$ & $4(44.44)$ & $2(22.22)$ & $3(33.33)$ & $4(44.44)$ \\
\hline Gentamicin $(10 \mu \mathrm{g})$ & $0(0)$ & $2(22.22)$ & $7(77.78)$ & $0(0)$ & $2(22.22)$ & $7(77.78)$ \\
\hline Erythromycin $(15 \mu \mathrm{g})$ & $0(0)$ & $2(22.22)$ & $7(77.78)$ & $9(100)$ & $0(0)$ & $0(0)$ \\
\hline Tetracycline $(30 \mu \mathrm{g})$ & $1(11.11)$ & $1(11.11)$ & 7 (77.78) & $2(22.22)$ & $2(22.22)$ & $5(55.56)$ \\
\hline Ampicillin $(10 \mu \mathrm{g})$ & $8(88.89)$ & $0(0)$ & $1(11.11)$ & $9(100)$ & $0(0)$ & $0(0)$ \\
\hline Polymixin B (300 unit) & $6(66.67)$ & $0(0)$ & $3(33.33)$ & $9(100)$ & $0(0)$ & $0(0)$ \\
\hline Chloramphenicol (30 $\mu \mathrm{g})$ & $2(22.22)$ & $2(22.22)$ & $5(55.56)$ & $2(22.22)$ & $1(11.11)$ & $6(66.67)$ \\
\hline Sulphamethoxazole $(25 \mu \mathrm{g})$ & $9(100)$ & $0(0)$ & $0(0)$ & $9(100)$ & $0(0)$ & $0(0)$ \\
\hline Streptomycin $(10 \mu \mathrm{g})$ & $1(11.11)$ & $8(88.89)$ & $0(0)$ & $4(44.44)$ & $4(44.44)$ & $1(11.11)$ \\
\hline Amoxycillin $(10 \mu g)$ & $8(88.88)$ & $0(0)$ & $1(11.11)$ & $9(100)$ & $0(0)$ & $0(0)$ \\
\hline Kanamycin $(30 \mu \mathrm{g})$ & $1(11.11)$ & $5(55.56)$ & $3(33.33)$ & $2(22.22)$ & $4(44.44)$ & $3(33.33)$ \\
\hline Ciprofloxacin $(5 \mu \mathrm{g})$ & $0(0)$ & $0(0)$ & $9(100)$ & $0(0)$ & $0(0)$ & $9(100)$ \\
\hline Nalidixic acid $(30 \mu \mathrm{g})$ & $2(22.22)$ & $0(0)$ & 7 (77.78) & $1(11.11)$ & $0(0)$ & $8(88.89)$ \\
\hline
\end{tabular}


In Bangladesh, oxytetracycline, amoxyciline, sulphamethoxazole, erythromycin are most commonly used antibiotics in aquaculture ${ }^{(42)}$. In this study, all 18 presumptively identified isolates exhibited multiple antibiotic resistance against 14 different antibiotics where all 18 isolates of Rohu and Silver carp including reference strain were resistant to sulphamethoxazole and sensitive to ciprofloxacin. Besides, around $89 \%$ bacterial isolates of Rohu revealed resistance to amoxyciline whereas all bacterial isolates of Silver carp were resistant to amoxyciline and erythromycin. So for controlling pathogenic gut microbiota ciprofloxacin $(5 \mu \mathrm{g})$ could be recommended.

Excessive antibiotics could remain in the sediment and alter the composition of microflora of the sediment ${ }^{(43)}$. The indiscriminate use of antibacterial agents in aquaculture promotes pathogenic gut microbiota to develop multiple antibiotic resistance by the formation of secondary metabolites or enzymes ${ }^{(44)}$. The studied fishes could act as a harbor of multiple antibiotic resistant bacteria( ${ }^{(45)}$.

In conclusion, this study confirms the existence of pathogenic bacteria in the gut of Rohu and Silver carp which is of public health concern. The bacterial load exceeded the acceptable limit of ICMSF (1986) due to poor water or feed quality, improper handling, unhygienic condition of markets as well as habitat or source from where the fish samples were collected. This experiment also suggests the abundance of antibiotic resistant pathogenic gastrointestinal bacteria in Rohu and Silver carp.

\section{Acknowledgements}

This work was partially funded by the National Science and Technology (NST) fellowship from Ministry of Science and Technology of the Government of Bangladesh. Authors are grateful to the Laboratory of Gene Biology of the Department of Biochemistry and Molecular Biology, University of Dhaka, for providing necessary laboratory facilities.

\section{References}

1. Shafi M and MMA Quddus 2004. Bangladesher Matsho Shampad (Fisheries of Bangladesh). 2nd (eds.) pp. 55 Kabir publications, Dhaka.

2. Xie P 1999. Gut contents of silver carp, Hypophthalmichthys molitrix, and the distribution of a centric diatom, Cyclotella, on passage through the esophagus and intestine. Aquaculture. 180: 295-305. doi: 10.1016/50044-8486(99)00205-7.

3. Sampson SJ, JH Chick and MA Pegg 2009. Diet overlap among two Asian carp and three native fishes in backwater lakes on the Illinois and Mississippi rivers. Biol. Invasions. 11: 483496. doi: 10.1007 /s10530-008-9265-7.

4. FRSS 2014. Fisheries Statistical Yearbook of Bangladesh. Fisheries resources survey system (FRSS). Bangladesh: Department of Fisheries. 30: 3. 
5. Saha S, RN Roy, SK Sen and AK Ray 2006. Characterization of cellulase-producing bacteria from the digestive tract of tilapia, Oreochromis mossambica (Peters) and grass carp, Ctenopharyngodon idella (Valenciennes). Aquac. Res. 37: 380-388. doi: 10.1111/.13652109.2006.01442.x.

6. Zoetendal EG, ADL Akkermans, VWM Akkermans-Van, DJAGM Visser and DWM Vos 2001. The host genotype affects the bacterial community in the human gastrointestinal tract. Microb. Ecol. Health Dis. 13: 129-134.

7. Li XM, YH Yu, WS Feng, QY Yan and YC Gong 2012. Host species as a strong determinant of the intestinal microbiota of fish larvae. J. Microbiol. 50: 29-37. doi: 10.1007/s12275-0121340-1.

8. Rahman SM, M Hasan, ZH Mahmud and SM Islam 2010. Bacterial load in twelve freshwater fishes of four feeding habits in Bangladesh. Dhaka univ. J. Biol. Sci. 19: 145-150. doi: 10.3329/dujbs.v19i2.8956.

9. Li J, J Ni, J Li, C Wang, X Li, S Wu, T Zhang, Y Yu and Q Yan 2014. Comparative study on gastrointestinal microbiota of eight fish species with different feeding habits. J. Appl. Microbiol. 117: 1750-1760. doi:10.1111 jam.12663.

10. Ye L, J Amberg, D Chapman, M Gaikowski and WT Liu 2014. Fish gut microbiota analysis differentiates physiology and behavior of invasive Asian carp and indigenous American fish. ISME J. 8: 541-551. doi: 10.1038/ismej.2013.181.

11. Ghosh K, M Roy, N Kar and E Ringo 2010. Gastrointestinal bacteria in rohu, Labeo rohita (Actinopterygii: Cypriniformes: Cyprinidae): scanning electron microscopy and bacteriological study. Acta. Ichthyol. Piscat. 40: 129-135. doi: 10.3750/AIP2010.40.2.05.

12. Venugopal V, SN Doke and P Thomas 1999. Radiation processing to improve the quality of fishery products. Crit. Rev. Food Sci. 39: 341-140. doi: 10.1080/10408699991279222.

13. Shaw KS, RER Goldstein, X He, JM Jocobs, BC Crump and AR Sapkota 2014. Antimicrobial susceptibility of Vibrio vulnificus and Vibrio parahaemolyticus recoverded from recreational and commercial areas of Chesapeake Bay and Maryland coastal Bays. Plos One. 9: 0089616. doi: 10.1371 journal.pone.0089616.

14. Alderman DJ and TS Hastings 1998. Antibiotic use in aquaculture: development of antibiotic resistance potential for consumer health risks. Int. J. Food Sci. Technol. 33: 139-155. doi: 10.1046/1.1365-2621.1998.3320139.x.

15. Xu H, R Ge and M Xiong 1988. Pathogenetic investigation of the enteritis of the grass carp (Ctenopharyngodon idellus). Acta. Hydrobiol. Sin. 12: 308-315.

16. Ringu E, RE Olsen, TM Mayhew and R Myklebust 2003. Electron microscopy of the intestinal microflora of fish. Aquaculture. 227: 395-415. doi: 10.1016 j.aquaculture.2003.05.001.

17. Janda JM and SL Abbott 2007. 16S rRNA gene sequencing for bacterial identification in the diagonistic laboratory: Pluses, Perils and Pitfalls. J. Clin. Microbial. 45: 2761-2764. doi: 10.1128 गCM.01228-07.

18. Rahman AKA 2005. Freshwater Fishes of Bangladesh. 2nd (eds), pp.122-123. Zool. Soc. Bangladesh, Dhaka, Bangladesh.

19. APHA (American Public Health Association) 1998. Standard Methods for the Examination of Water and Wastewater. 20th ed. American Public Health Association, Washington DC.

20. Beveridge MCM, PK Sikdar, GN Frerichs and S Millar 1991. The ingestion of bacteria in suspension by the common carp Cyprinus carpio L. J. Fish Biol. 39: 825-831. doi: 10.1111\}.1095-8649.1991.tb04412.x. 
21. Buchanan RE and NR Gibbons 1974. Bergey's Manual of Determinative Bacteriology. 8th (eds). Baltimore, Williams \& Wilkins.

22. Hudzicki, J 2009. Kirby-Bauer disc diffusion susceptibility test protocol. American Society for Microbiology, Washington DC.

23. Adams MR and MO Moses 2008. Food Microbiology. 3rd (eds), pp. 179 The Royal Society of Chemistry, UK. doi: 10.1039 9781847557940.

24. ICMSF 1986. Microorganism in Food. In: Application of the Hazard Analysis Critical Control Point (HACCP) System to Ensure Microbiological Safety and Quality. 2nd (eds.), pp. 181195, 42, New Jersey: Blackwell Scientific Publications.

25. Campbell AC and JA Buswell 1983. The intestinal microflora of farmed Dover sole (Solea solea) at different stages of fish development. J. Appl. Bacteriol. 55: 215-223. doi: 10.1111 \.13652672.1983.tb01318.x.

26. Wu S, G Wang, ER Angert, W Wang, W Li and H Zou 2012. Composition, diversity and origin of the bacterial community in grass carp intestine. PLoS One. 7: e30440. doi: 10.1371 journal.pone.0030440.

27. Frank JA, CI Reich, S Sharma, JS Weisbaum, BA Wilson and GJ Olsen 2008. Critical Evaluation of Two Primers Commonly Used for Amplification of Bacterial 16S rRNA Genes. Appl. Environ. Microbiol. 74: 2461-2470. doi: 10.1128/AEM.02272-07.

28. Isonhood JH and M Drake 2002. Aeromonas species in foods. J. Food Protect. 65: 575-582.

29. Ariole CN, HA Nwogu and PW Chuku 2014. Enzymatic activities of intestinal bacteria isolated from farmed Clarias gariepinus. International Journal of Aquaculture. 4: 108-112. doi: 10.5376/jja.2014.04.0018.

30. Tamura $\mathrm{T}$ and $\mathrm{T}$ Hida 2003. A case of endogenous Aeromonas hydrophila endophthalmitis. Nippon Ganka Gakkai Zasshi. 107: 535-537.

31. Demarta A, M Tonolla, A Caminada, M Beretta and R Peduzzi 2000. Epidemiological relationships between Aeromonas strains isolated from symptomatic children and household environments as determined by ribotyping. Eur. J. Epidemiol. 16(5): 447-453.

32. Austin B and C Adams 1996. Fish pathogens. In: The Genus Aeromonas (Austin B, M Altwegg, PJ Gosling and S Joseph). pp. 198-243 Wiley, Chichester, UK.

33. Hardalo C and SC Edberg 1997. Pseudomonas aeruginosa: assessment of risk from drinking water. Crit. Rev. Microbiol. 23: 47-75. doi: 10.3109/10408419709115130.

34. Kumari S, BN Prasad, G Kumari, A Quasim, BK Sinha and JN Singh 2001. Microbiological quality of fish, Rohu marketed in Patna and its public health significance. J. Food Sci. Tech. 38: 607-608.

35. Trakroo MD and R Agarwal 2011. Qualitative and quantitative study on bacterial flora of farm raised Rohu, Labeo rohita (Ham.) in India. J. Recent Trends Biosci. 1: 66-71.

36. Bodey GP, R Bolivar, V Fainstein and L Jadeja 1983. Infections caused by Pseudomonas aeruginosa. Rev. Infect. Dis. 5: 279-313.

37. O'Toole GA and R Kolter 1998. Flagellar and twitching motility are necessary for Pseudomonas aeruginosa biofilm development. Mol. Microbiol. 30: 295-304. 
38. Sidorczyk Z, AS Wierzko, YA Knirel, EV Vinogradov, AY Chernyak, LO Kononov, M Cedzynski, A Rozalski, W Kaca, AS Shashkov and NK Kochetkov 1995. Structure and epitope specificity of the O-specific polysaccharide of Proteus penneri 12 (ATCC33519) containing the amide of D-galacturonic acid with L-threonine. Eur. J. Biochem. 230: 713-721.

39. Sinha DK, SP Choudhary and KG Narayan 1991. Microbiological characteristics of marketed rohu (Labeo rohita). Indian J. Fish 38: 69-71.

40. Abel E, RV Pakingking Jr, G Pagador, MT Wint and F Huyop 2012. Characteristics of dehalogenase from bacteria isolated from the gut of pond-reared rohu (Labeo rohita) juveniles in Myanmar. Advances in Bioscience and Biotechnology. 3: 353-361. doi: 10.4236/abb.2012.34051.

41. Ray AK, T Roy, S Mondal and E Ringo 2010. Identification of gut-associated amylase, cellulose and pro- tease-producing bacteria in three species of Indian major carps. Aquac. Res. 41: 1462-1469. doi:10.1111\}.1365-2109.2009.02437.x.

42. Graslund S and BE Bengtsson 2001. Chemicals and biological products used in south-east Asian shrimp farming and their potential impact on the environment- A review. Sci. Environ. 280: 93-131. doi: 10.1016/\$0048-9697(01)00818-X.

43. Sorum H 2006. Antimicrobial Resistance in Bacteria of Animal Origin. In: Antimicrobial Drug Resistance in Fish Pathogens (Aarestrup FM) pp. 213-238 American Society for Microbiology, Washington DC. doi: 10.1128/9781555817534.ch13.

44. Sugita H, Y Hirose, N Matsuo and Y Deguchi 1998. Production of the antibacterial substance by Bacillus sp. strain NM 12, an intestinal bacterium of Japanese coastal fish. Aquaculture. 165: 269-280. doi: 10.1016 \$0044-8486(98)00267-1.

45. Ryu SH, SG Park, SM Choi, YO Hwang, HJ Ham, SU Kim, YK Lee, MS Kim, GY Park, KS Kim, YZ Chae 2012. Antimicrobial resistance and resistance genes in Escherichia coli strains from commercial fish and seafood. Int. J. Food Microbiol. 15: 14-18. doi: 10.1016ð.ijfoodmicro.2011. 10.003. 